\title{
Ilegitimidade como forma: uma leitura de Angústia, de Graciliano Ramos
}

\author{
Willy Carvalho Coelho \\ Doutorando em Literatura Comparada do Programa de Pós-Graduação em \\ Estudos Literários / UFMG
}

\begin{abstract}
RESUMO
Análise e crítica do processo de composição do romance Angústia (1936), de Graciliano Ramos. O trabalho apresenta breve histórico do protocolo de composição e da recepção do livro pela crítica. Em seguida, propõe a leitura do texto pela noção de ilegitimidade, depreendida da crítica do texto e da crítica histórico-cultural do contexto de sua produção.
\end{abstract}

\section{PALAVRAS-CHAVE}

Graciliano Ramos, Angústia (1936), ilegitimidade

\section{INTRODUÇÃO}

Angústia foi o terceiro livro publicado por Graciliano Ramos. O romance foi escrito durante o ano de 1935 e parte de 1936. Graciliano relata que finalizou a revisão da última versão manuscrita em 03 de março de $1936 .{ }^{1}$ No fim da tarde do mesmo dia, o escritor fora preso por força policial do Exército do governo de Getúlio Vargas.

O terceiro romance de Graciliano nasce de um conto, redigido nos anos de 1920 como exercício de estilo para distrair o tédio provinciano. O texto se configura como uma espécie de embrião da narrativa que será desenvolvida em Maceió. ${ }^{2}$ Graciliano se mudara havia pouco, estabelecendo-se com a família na capital. Nesse tempo, exerce a função de diretor na Instrução Pública do Estado.

\footnotetext{
${ }^{1}$ RAMOS. Memórias do cárcere, p. 44.

${ }^{2}$ MORAES. O velho Graça: uma biografia de Graciliano Ramos, p. 47.
} 
A imagem do zigue-zague foi usada para representar o método de composição adotado em Angústia. ${ }^{3}$ O romance foi, em mais de uma ocasião, analisado e descrito como uma espécie de fenomenologia do funcionamento da mente perturbada de Luís da Silva, narrador e personagem principal do romance. Lançando mão do recurso do monólogo interior, Graciliano Ramos ajusta o ponto de vista do seu narrador em primeira pessoa valendo-se do arranjo técnico que conjuga o uso da memória enxertada pela imaginação. O livro relata história contemporânea ao tempo histórico de sua elaboração. Luís da Silva se propõe a nos contar os fatos acontecidos havia pouco mais de um ano antes da decisão de iniciar sua narrativa, num período delimitado, e passível de demonstração no texto do romance, entre os anos da década de 1930, necessariamente após o golpe da Revolução de 30, e o ano de sua conclusão, 1936. Mas o discurso de Luís da Silva está longe da noção de organização narrativa tradicional, em que se pode acompanhar o desenrolar do enredo linear da história. Graciliano Ramos impõe ao narrador de Angústia a incumbência de resgatar a memória do tempo vivido na infância como dever e possibilidade de esclarecimento dos atos e da circunstância do presente. Daí a noção de zigue-zague. Luís da Silva transita entre a memória da infância, vivida junta aos avós paternos e a figura do pai, representantes de uma classe em extinção - pequenos senhores de terras e de escravos - em decorrência às mudanças estruturais da economia e das relações e regimes políticos, e o tempo presente, marcadamente incongruente. Nessa tarefa de resgatar a memória passada e avaliar o presente, inapreensível por esquemas rígidos e maniqueístas, nesse zigue-zague entre tempos e panoramas atordoantes, Luís da Silva capta e nos apresenta através de sua narrativa “desordenada” um painel da formação cultural e social brasileira em que o tema da legitimidade da representação do poder se deixa depreender. Essa é a tese principal deste trabalho. O romance que fora originalmente lido numa perspectiva preponderantemente psicológica apresenta, sob o enfoque que conjuga a crítica do texto e a pesquisa histórico-cultural, outro elemento ordenador da narrativa que sustenta a estrutura formal do romance. Além de se apoiar nos preceitos técnicos da investigação psicológica, a investigação da mente criminosa e da loucura, o romance propõe a crítica da legitimidade do contexto político e da ordenação do poder através da forma literária.

\footnotetext{
${ }^{3}$ LINS. Valores e misérias das vidas secas, p. 144.
} 


\section{CENAS DA COMPOSIÇÃO E DA RECEPÇÃO DE ANGÚSTIA}

A recepção crítica de Angústia variou significativamente desde sua publicação em agosto de 1936. O livro foi recebido com entusiasmo pelo meio literário e intelectual da época, movido pelo interesse nas circunstâncias e pelo sentimento de solidariedade que a prisão do autor suscitavam. Pode-se juntar ao fato o recente reconhecimento da obra do autor pelos lançamentos de Caetés, em 1933, e S. Bernardo, em 1934, por editoras do Rio de Janeiro. O romance percorreu o trajeto que vai da concessão do Prêmio Lima Barreto (em sua primeira versão), oferecido pela Revista Acadêmica, à marginalidade crítica, após algum tempo de seu lançamento. Fato constatável, por exemplo, pelo trabalho de Lúcia Helena Carvalho, que aponta o descenso da recepção que condenava Angústia à marginalidade como falta de preparo da crítica, somado à carga de inovação estética trazida pela obra. ${ }^{4}$

O impacto da inovação técnica e estilística de Angústia pode ser confirmado pela constatação de Álvaro Lins, já em 1941, de que o romance "representa um caso de estudo crítico muito difícil para os seus contemporâneos”. 5 O crítico inicia o canônico ensaio sobre a obra de Graciliano Ramos, Valores e misérias das vidas secas, apontando Angústia como romance "principal” do autor. Ao mesmo tempo, ratifica a informação da acolhida entusiasmada da crítica contemporânea, para, mais à frente, reconhecer o romance como "a obra-prima” de Graciliano. ${ }^{6}$ Apesar da hesitação sugerida, o crítico realiza, junto com colegas importantes de sua geração, crítica relevante, e ainda atual, sobre a construção do romance.

Angústia contou com a crítica contemporânea de Antonio Candido. Apesar de não o reconhecer como obra-prima, o crítico, ciente dos recursos estéticos inovadores do texto, avalia o livro como "o mais ambicioso e espetacular de quantos escreveu” o autor. ${ }^{7} \mathrm{O}$ afastamento do objeto, que o tempo possibilita, terá como efeito a nova visada e o consequente deslocamento da expectativa de recepção da mensagem e do trabalho estético,

\footnotetext{
${ }^{4}$ CARVALHO. A ponta do novelo, p. 20-21.

${ }^{5}$ LINS. Valores e misérias das vidas secas, p. 136.

${ }^{6}$ LINS. Valores e misérias das vidas secas, p. 153.

${ }^{7}$ CANDIDO. Fiç̧ão e confissão, p. 47.
} 
a ponto de Wander Melo Miranda, crítico responsável pela reedição crítica da obra do autor, restaurar o status de obra-prima do livro. ${ }^{8}$

Luís Bueno, em recente trabalho histórico-literário, faz um levantamento minucioso sobre essa oscilação pela qual Angústia passou. ${ }^{9}$ Guardando a devida preocupação de demonstrar que, apesar da ambivalência característica do julgamento do próprio autor sobre seu trabalho, Luís Bueno nos demonstra que o livro foi eleito um dos melhores romances brasileiros por críticos de orientação reconhecidamente díspar, como Octávio de Faria e Lúcio Cardoso, Rachel de Queirós e Jorge Amado, para se ter uma ideia fidedigna do contexto de sua recepção. ${ }^{10}$

O trabalho de Graciliano é indissociável da experiência da vida. Já notavam essa simbiose os primeiros críticos de seu texto. Angústia, particularmente, foi lido de forma muito próxima da experiência mesmo autobiográfica, como aponta com pertinência Antonio Candido e os trabalhos posteriores que o leram por uma chave preponderantemente psicológica. Sem desconsiderar essa avaliação, que a meu ver continua atual e pertinente, apropriar-me-ei de sua intenção analítica para contrabalançar a proposta atual de análise da construção do romance.

O romance Angústia, narrado pelo personagem principal, o funcionário público e escritor diletante Luís da Silva, inicia-se com a seguinte enunciação:

Levantei-me há cerca de trinta dias, mas julgo que ainda não me restabeleci completamente. Das visões que me perseguiam naquelas noites compridas umas sombras permanecem, sombras que se misturam à realidade e me produzem calafrios. ${ }^{11}$

Num exercício de hermenêutica selvagem, é fácil perceber, logo no início do livro, que o narrador, que se propõe a nos relatar a história que se estenderá por duzentas e tantas páginas, decide, após o período de convalescença e quase trinta dias da consciência de seu

\footnotetext{
${ }^{8}$ MIRANDA. Graciliano Ramos, p. 33.

${ }^{9}$ BUENO. Uma história do romance de 30, p. 619-623.

${ }^{10}$ Trata-se de inquérito realizado, junto a escritores e críticos, por Murilo Miranda, editor da Revista Acadêmica, veículo importante de divulgação e crítica literária e cultural da época. (Cf. BUENO. Uma história do romance de 30, p. 622.)

${ }^{11}$ RAMOS. Angústia, p. 7. A edição utilizada é de 2005 da Editora Record, que tem como base a $4^{\text {a }}$ edição, publicada pela J. Olympio, com as últimas correções feitas por Graciliano Ramos, e faz parte do projeto de reedição da obra do autor, supervisionado pelo Prof. Wander Melo Miranda, da Universidade Federal de Minas Gerais.
} 
restabelecimento, narrar sobre o transtorno ou doença que o acometera - doença senão designada sugerida: "visões que me perseguiam naquelas noites compridas.”

Se seguíssemos nesse exercício, perceberíamos que levaria certo tempo para o esclarecimento mínimo da posição e da natureza da voz narrativa que estamos a acolher. ${ }^{12}$ Todo o relato da primeira micronarrativa, além de arrolar, sem maiores detalhes, os nomes de bom número de personagens importantes do romance, suscita a ambiência afetiva de atordoamento mental do narrador. O tom sugere pessimismo e uma espécie de defesa psicológica que almeja separar radicalmente o mundo e a experiência interna ou subjetiva, muito provavelmente motivada pelo amálgama contraditório, formado pelas emoções de "tristeza e raiva", 13 explicitamente enunciadas pelo narrador.

O trecho vale mais pelo que nele há de conotação, como preâmbulo para a história que Luís da Silva nos contará. Entre sombras e a confissão contemporânea de que a realidade se deixa apreender apenas através de fragmentos, Luís da Silva empreenderá a narrativa que, se é atravessada pelo amargor da frustração, como já apontara Antonio Candido, não é menos honesta e coerente com o método da verossimilhança e com a experiência humana na Modernidade.

Luís da Silva, atento e obediente à lógica da elaboração textual, como é de se esperar de um escritor, nos fornece, bem no início de seu relato, algo parecido com uma teoria da narrativa ou o esboço de uma poética pessoal que dirige o texto:

Lembro-me de um fato, de outro fato anterior ou posterior ao primeiro, mas os dois vêm juntos. E os tipos que evoco não têm relevo. Tudo empastado, confuso. Em seguida os dois acontecimentos se distanciam e entre eles nascem outros acontecimentos que vão crescendo até me darem sofrível noção de realidade. As feições das pessoas ganham nitidez. De toda aquela vida havia no meu espírito vagos indícios. Saíram do entorpecimento recordações que a imaginação completou. ${ }^{14}$

O compromisso de narrar se confunde e encena a necessidade sincera de confidenciar uma experiência que se coloca, em sugestão, como provação.

A escolha da primeira pessoa não seria casual. Graciliano vem das experiências anteriores de Caetés e de $S$. Bernardo, que, se guardam semelhança quanto ao foco

${ }^{12}$ Rui Mourão aponta o fato, no trabalho minucioso de close reading dos romances do autor, enfatizando o estranhamento diferido do início de Angústia. (Cf. MOURÃO. Estruturas: ensaio sobre o romance de Graciliano, p. 87-88.)

${ }^{13}$ MOURÃO. Estruturas: ensaio sobre o romance de Graciliano, p. 9.

${ }^{14}$ RAMOS. Angústia, p. 18-19. 
narrativo, compreendido em sua faceta "técnica”, não deixam de apresentar diferenças evidentes. O relato em primeira pessoa dará mais semelhança de realidade, mesmo que confessada e sinceramente o narrador admita que os hiatos da memória sejam preenchidos pela imaginação.

O baralhamento dos “acontecimentos” sugerido pelo narrador foi notado por Rui Mourão. Quanto à estrutura de Angústia, o crítico manifesta a impressão de estar diante de "uma caixa que sai de dentro de outra caixa, que por sua vez sai de dentro de outra caixa”. 15

Atento ao processo de construção do romance, Álvaro Lins, aliando a fina observação do trabalho com a linguagem, o contexto literário e o influxo de informações biográficas, corrobora e acompanha o traçado do projeto da narrativa de Luís da Silva.

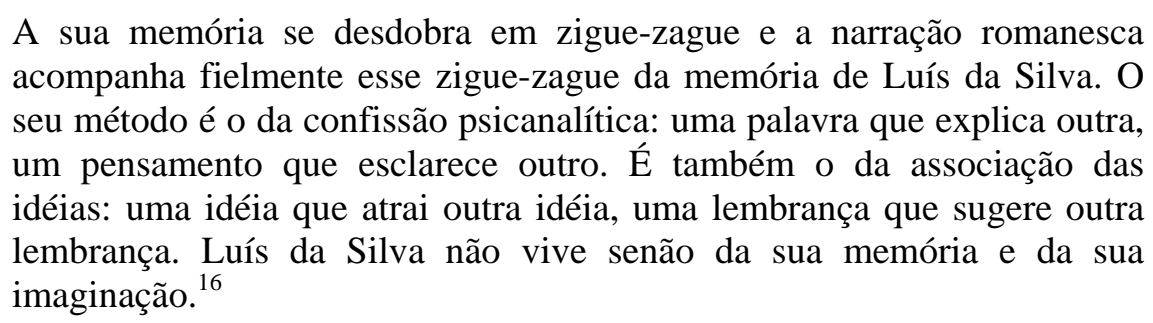

Atentando o desenvolvimento narrativo, entre "memória” e "imaginação”, Álvaro Lins inicia uma linha crítica que prioriza o enfoque psicológico ou a pesquisa do "homem" que o romance suscita, projetando luz, com o auxílio da teoria psicanalítica, sobre o processo de composição do romance.

Lúcia Helena Carvalho, por sua vez, descreve a estruturação do romance utilizando a categoria mise-en-abyme, a "construção em abismo", traçando o histórico do uso da técnica no romance moderno. ${ }^{17}$

Angústia é todo o relato de Luís da Silva. Não seria exagero dizer que o livro é seu narrador, desdobrado nos outros elementos da estrutura da obra literária. Antonio Candido diz num ponto de Fiç̧ão e confissão: "Em Angústia, o narrador tudo invade e incorpora à sua substância, que transborda sobre o mundo.”18 Se há descrições, diálogos, estes são devidamente controlados e dosados, e o que se sobrepõe é o discurso, a narração, a voz em

\footnotetext{
${ }^{15}$ MOURÃO. Estruturas: ensaio sobre o romance de Graciliano, p. 101.

${ }^{16}$ LINS. Valores e misérias das vidas secas, p. 144.

${ }^{17}$ CARVALHO. A ponta do novelo: uma interpretação de Angústia de Graciliano Ramos, p. 5-19.

${ }^{18}$ CANDIDO. Fiç̧ão e confissão, p. 56-57.
} 
discurso direto de Luís da Silva no uso da técnica do "monólogo interior", ${ }^{19}$ que está a construir seu livro através das "notas" tomadas na mesa da cozinha de sua casa, um ano e pouco após os acontecimentos que compõem a história em primeiro nível do livro.

\section{LITERATURA, HISTÓRIA, CULTURA}

Qual panorama social Graciliano Ramos observa nos idos dos anos de 1930?

Sabemos que, apesar de Angústia apresentar a história contemporânea do tempo de sua elaboração, Graciliano Ramos impõe a Luís da Silva a tarefa de resgatar tempo histórico que coincide tanto com a infância do narrador-personagem quanto com período histórico da formação sociocultural do Brasil, Um tempo marcado pela transição entre regimes sociais e políticos distintos. O efeito da transição de ordens se fará sentir na organização social (ampla) do país. Contando 35 anos no momento que decide iniciar a narrativa, Luís da Silva vivencia, na infância, o momento de transição definidor para os rumos do país; a mudança de regime político e todas suas implicações: o advento da República, com a deposição do Imperador, os reflexos da abolição (atrasada) da escravidão, o crescimento da urbanização, o aumento de mão de obra livre e dependente.

Eu andava no pátio, arrastando um chocalho, brincando de boi. Minha avó, sinhá Germana, passava os dias falando só, xingando as escravas, que não existiam. Trajano Pereira de Aquino Cavalcante e Silva tomava pileques tremendos. Às vezes subia à vila, descomposto, um camisão vermelho por cima da ceroula de algodão encaroçado, chapéu de ouricuri, alpercatas e varapau. Nos dias santo, de volta da igreja, mestre Domingos, que havia sido escravo dele e agora possuía venda sortida, encontrava o antigo senhor escorado no balcão de Teotoninho Sabiá, bebendo cachaça e jogando três-setes com os soldados. O preto era um sujeito perfeitamente respeitável. Em horas de solenidade usava sobrecasaca de chita, correntão de ouro atravessado de um bolso a outro do colete, chinelos de trança, por causa dos calos, que não agüentavam sapatos. Por baixo do chapéu duro, a testa retinta úmida de suor, brilhava como um espelho. Pois, apesar de tantas vantagens, mestre Domingos, quando via meu avô naquela desordem, dava-lhe o braço, levava-o para casa, curava-lhe a bebedeira com amoníaco. Trajano Pereira de Aquino Cavalcante e Silva vomitava na sobrecasasa de mestre Domingos e gritava:

- Negro, tu não respeitas teu senhor não, negro! $!^{20}$

As lembranças da infância de Luís da Silva, narradas logo no início do texto, rememoram o tempo vivido junto aos avós paternos e descrevem a senilidade patética do

\footnotetext{
${ }^{19}$ CANDIDO. Fiç̧ão e confissão, p. 56.

${ }^{20}$ RAMOS. Angústia, p. 13-14.
} 
patriarca que enverga o suntuoso nome, Trajano Pereira de Aquino Cavalcante e Silva. O episódio da relação entre o senhor de terras arruinado e o ex-escravo dá bem a ideia da incorporação do elemento social em Angústia. A demência do avô era aguçada pela conjuntura histórico-cultural que redefinia o arranjo dos atores sociais após longo período de estabilização de um sistema em que os senhores de terras gozavam de privilégios mantidos pelas relações próximas com os representantes do poder. ${ }^{21}$ A escrita pautada no “zigue-zague”, definido pelo amálgama da memória e da imaginação, transgride os códigos literários e sociais e encaminha o narrador para regiões indesejáveis, colocando-o diante do seu próprio desejo, como lembra Wander Melo Miranda. ${ }^{22}$ Desejo e lembranças relegadas ao esquecimento, até o momento do acerto pela escrita. A “pequena verdade” de Luís da Silva, como diria Graciliano Ramos, que toda sua vida regrada e estabelecida por regulamentos fazia questão de manter na obscuridade, não pode mais ser ignorada. A angústia a que o título do livro faz referência é facilmente apreendida quando confluímos a análise psicológica do narrador e o contexto histórico e social pelo qual ele circula. A sensação de angústia é reação natural no ser humano. É uma defesa necessária à formação do discernimento e do comportamento adaptativo, responsável por nos proteger diante da variabilidade de circunstância de perigo que a vida cultural e social apresenta na atualidade. A variação de intensidade e do curso da manifestação do sentimento da angústia indicia algo de ordem patológica. É preciso lembrar que a angústia que envelopa os fatos narrados por Luís da Silva se direciona ao futuro do narrador criminoso. Liga-se, dessa maneira, à repercussão do ato praticado pelo narrador, móbil da narrativa retrospectiva, tanto num plano individual - a expiação da culpa ou a possibilidade de uma pena - quanto social - a incerteza do futuro do país, marcado pela instabilidade política. O que vale indagar é a que preço Luís da Silva conseguiu manter a administração do sintoma da “angústia” precedente ao assassinato, e que função ele apresenta na arquitetura da obra. Sabemos a resposta para a primeira questão. Quanto à função de representar a realidade pela lente de narrador dividido entre duas ordens sociais e culturais delimitadas, que o equilibra entre o conformismo e o anseio quanto ao futuro, não se pode prescindir do contexto histórico para esclarecer a constrição causada pelo sentimento de angústia. Na ruptura das racionalizações que o mantinham estabilizado numa identidade social - frágil,

\footnotetext{
${ }^{21}$ FAORO. Os donos do poder: formação do patronato político brasileiro, p. 741-818.

${ }^{22}$ MIRANDA. Graciliano Ramos, p. 35-36.
} 
mas eficiente por um tempo -, o ato advém no lugar da palavra que não significa mais nada.

É preciso reconhecer que a incorporação de elementos históricos definidos, realizada pela estrutura da narrativa de Luís da Silva, abrange o recorte do social compatível com os elementos literários arquitetados na composição do livro. Dessa maneira, o autor foca a estrutura social do ambiente da Maceió dos anos de 1930 e define na figura de Luís da Silva o narrador participante que o ambiente demanda. O intelectual, herdeiro de proprietários de terras falidos, se vê relegado à vida social na cidade, diminuída em status, trabalhando como funcionário público. Nessa condição, o narrador de Angústia, guardando a honestidade e a verossimilhança do relato, pode contemplar, apenas indiretamente, as faixas que formam a pirâmide social. Luís da Silva recebe ordens por escrito do secretário e do chefe da repartição. Convive com Moisés, o amigo judeu de ideias revolucionárias, que trata com condescendência, por dever ao tio do rapaz certa quantia em dinheiro. Conhece Julião Tavares, bacharel, filho de comerciantes, representante da burguesia urbana (em ascensão, na nova organização social), numa festa do Instituto Histórico e Geográfico, em que comparece, apesar de se sentir deslocado, pela vaidade e fantasia de futuro reconhecimento literário. Tenta, em vão, sentir empatia e travar diálogo com trabalhadores braçais e representantes do lumpemproletariado. Relaciona-se com Marina e sua família, que veem em sua figura representante de classe superior, e se surpreende quando a mãe da moça solicita-lhe intervenção para "cavar emprego” para a filha. Da alta esfera do poder consegue apenas especular os rumos que cada um teria diante da concretização dos boatos alardeados, a todo canto, da iminência da “revolução”. Especula sobre a vida de Julião Tavares, pergunta-se o que será do diretor, do chefe da repartição, assim como o que seria feito de um sujeito como ele numa revolução de trabalhadores. Mesmo revelando a realidade periférica da região em que se encontra em relação ao país, o relato denota o fluxo das influências, “a malandragem política” e "a ruína da burguesia”, a viscosidade da cena política e social, depreendida dos acontecimentos políticos no contexto nacional. Embora restrito, o recorte social de Angústia define relevante elemento ordenador da narrativa, essencial à compreensão da forma do romance. Graciliano Ramos realiza a apreensão corajosa dos efeitos da modernidade tardia, e tangencial, acontecida no país. 


\section{PoDER, LEGITIMIDADE, RESPONSABILIDADE, LIBERDADE}

A cena política representada pelos arranjos e negociações escusas é uma faceta captada por Angústia. Da incorporação desse referencial, o texto do romance se dirige para o diagnóstico sombrio da incongruência e do convívio entre a retórica da ordem e o fato da desordem apreendida pela forma do texto através da noção de ilegitimidade.

A equação que a teoria do poder traça a respeito da legitimidade pressupõe o exercício da liberdade. A legitimidade se sustenta em torno de "valores"; valores que apenas a razão que guarda a capacidade de se autoquestionar pode traçar. Razão motivada pelas questões que fundamentam a legitimidade: por que obedecer? Por que consentir? Mesmo que não se apoie ou participe ativamente das decisões do governo, o contexto do poder legítimo pressupõe a salvaguarda ao indivíduo da liberdade de avaliar e refletir sobre os valores que cercam as ações dos representantes do governo. O tempo de reflexão concede-lhe, em consequência, o direito de opinar dentro das regras que regulam o sistema político e social. Um bom exemplo é a conjunção entre o republicanismo e o governo democrático respaldado na regulamentação dos poderes do governo através de uma constituição que assegure o sufrágio universal. ${ }^{23} \mathrm{Na}$ falta de melhor dispositivo de organização e controle do poder, prefiro pensar que ainda assim é melhor ter o direito de votar livremente entre as opções que me apresentam. Não se circunscrevendo à opinião pessoal, a leitura que apresento da forma do romance Angústia, partindo do referencial que se equilibra entre a visada e a demonstração dos elementos do projeto estético de Graciliano Ramos e a crítica do contexto histórico e cultural em que sua produção se assenta, deriva a proposição interpretativa da função da narrativa em Angústia, depreendida da forma do romance, lançando mão da noção da ilegitimidade.

A narrativa empreendida por Luís da Silva foi identificada de forma quase homogênea no longo trajeto crítico do texto como um relato desordenado, atípico e tendente ao excesso, ao transbordamento verbal, e bastante distinto do que se vinha realizando na tradição literária brasileira. A observação, na maioria dos casos, fora enunciada como avaliação negativa de um traço do romance. Mesmo quando associava o uso da linguagem desenvolvida pelo narrador à representação do seu estado psicológico, a

\footnotetext{
${ }^{23}$ Remeto o leitor ao ensaio de Renato Janine Ribeiro, Democracia versus República: a questão do desejo nas lutas sociais, em que o autor discorre sobre a natureza dos conceitos que representam os regimes políticos, e a interdependência que define a relação entre as configurações do poder na atualidade. (Cf. RIBEIRO. Democracia versus República: a questão do desejo nas lutas sociais, p. 13-26.)
} 
crítica pioneira do romance tendeu a avaliar a repetição excessiva de temas e a transposição incessante de tempos da história relatada (exploração da memória como método narrativo) de forma negativa e defeituosa. Essa opinião foi compartilhada por críticos como Álvaro Lins, Otto Maria Carpeaux e Antonio Candido. Notamos que, apesar da avaliação negativa, no que concerne à modulação do discurso do narrador, é unânime a opinião dos críticos o fato de o romance de 1936 constituir trabalho original e arrojado, em que a fatura do texto compensa o excesso estilístico adotado. Após a primeira geração da crítica, a recepção do romance abre-se para novas perspectivas, tendendo a avaliar o processo de composição pela inovação estética experimental que seu texto propõe. Os trabalhos de Carlos Nelson Coutinho, Letícia Malard e Lúcia Helena Carvalho dão testemunho do reconhecimento inovador da composição empreendida em Angústia, associada por vezes a trabalhos da vanguarda do início do século 20. Da mesma forma, trabalhos críticos mais próximos de nós no tempo reconsideram os critérios na acolhida que fazem do texto do romance, ressaltando a inovação estética e a peculiaridade do projeto de Angústia; exemplos relevantes são os textos de Silviano Santiago, Wander Melo Miranda e Luís Bueno.

De minha parte, subscrevo a ideia de que o arranjo técnico da narrativa de Luís da Silva, texto elaborado para suscitar a aparência de desorganização e desordem, mantém relação direta com o efeito provocado pela apreensão da forma do romance. Por essa perspectiva, o que fora avaliado como defeito torna-se componente estético indispensável à compreensão global da estruturação do texto.

O leitor conhecedor do universo da obra de Graciliano Ramos poderá atribuir a característica da aparência de texto inacabado de Angústia às circunstâncias factuais de sua elaboração e à falta de finalização com a devida revisão da cópia datilografada e do manuscrito. Não negligencio o fato. Ouçamos o autor:

Essa confirmação da proposta, que Rodolfo me trouxera da Polícia Central, na semana anterior, sobressaltou-me. Era-me indispensável rever aquilo, emendar os erros cometidos pela datilógrafa. E erros meu também. Temeridade a publicação. Tencionei contrabandear os papéis, corrigi-los antes de serem remetidos à tipografia, mas afastei logo a idéia. Com a fiscalização rigorosa, não conseguiria recebê-los (...) Não me arriscaria a trazer para o cubículo, por intermédio de minha mulher, o romance falho. Embora ele valesse pouco, era-me desagradável perdê-lo. $\mathrm{O}$ original e a outra cópia recomendada existiriam? Afinal o romance 
valia pouco. Ser-me-ia talvez possível, com dificuldade, fazer outro menos ruim. ${ }^{24}$

Continuava apático e vazio; momentos de otimismo fugaz davam-me, entretanto, a esperança de concluir um dia a lenta redação das folhas pesadas. A cópia da história nebulosa e medonha chegara do nordeste, fora enviada à tipografia. Os críticos iriam arrasar-me. Ou não arrasariam; o mais certo era não dizerem nada. ${ }^{25}$

Em Memórias do cárcere, Graciliano Ramos nos oferece vários pontos de esclarecimento sobre o processo de composição do romance Angústia que não se limitam a critérios meramente técnicos e à apresentação da circunstância da escrita do texto. ${ }^{26}$ Além dos excertos citados, vale lembrar a informação presente no terceiro capítulo de Memórias do cárcere, no qual Graciliano Ramos relata o evento de sua prisão no mesmo dia em que finaliza e encaminha o manuscrito do romance para ser datilografado. ${ }^{27}$ Penso que o livro acerca das memórias da prisão volta-se com especial interesse para o romance de 1936 por manter com ele semelhanças quanto ao projeto estético.

O livro de memórias, além do fato de não ter sido formalmente acabado, faz-se a principal fonte de esclarecimento da repercussão do projeto literário do autor, e em particular, do projeto estético de Angústia, por sua vez, romance que encena literariamente o discurso autobiográfico e memorialístico posto em marcha por um intelectual, narrador ficcional. A minha proposição é que, se seguirmos o trajeto coerente e honesto da obra do autor, cujo compromisso se funda na responsabilidade do escritor frente à instituição que a literatura representa, o fato de não dar por acabado, não concluir, ou finalizar o texto de Angústia, assim como a de Memórias do cárcere, demonstra a consciência da responsabilidade frente à circunstância histórica que demandava ideologicamente a aparência da ordem e exortava o ímpeto à totalidade como simulacro da realidade. Graciliano Ramos, refratário ao embuste ideológico, mexe-se nos estreitos limites da liberdade de expressão através da palavra escrita. Mesmo que a ficção de Angústia represente o tempo circular e paralisante da modernização brasileira, falaciosa e incompleta - uma "viagem redonda”, em que não há progresso genuíno, como sugerido

\footnotetext{
${ }^{24}$ RAMOS. Memórias do cárcere, p. 274-275.

${ }^{25}$ RAMOS. Memórias do cárcere, p. 291.

${ }^{26}$ Hermenegildo Bastos aponta um nível importante do discurso de Memórias do cárcere em que vemos o "autor (...) convertido (...) em leitor de sua obra”. (Cf. BASTOS. Memórias do cárcere: literatura e testemunho, p. 75-77.)

${ }^{27}$ RAMOS. Memórias do cárcere, p. 44-49.
} 
por Raymundo Faoro, no capítulo final de Os donos do poder, ${ }^{28}$ o desenvolvimento da obra nos conscientiza de que o texto moderno é estruturalmente aberto e inconcluso por que a história continua, ou pode ser lida de outro ponto de vista, ${ }^{29}$ o que a migração da ficção para a confissão, redundando em Memórias do cárcere, demonstra de forma exemplar.

O título Memórias do cárcere não foi finalizado. "Faltava apenas um capítulo”, para sua conclusão. ${ }^{30}$ Ricardo Ramos trata de esclarecer as circunstâncias que rodeiam a publicação póstuma do livro de memórias. ${ }^{31} \mathrm{O}$ que nos interessa é a discussão travada pelo escritor, filho do autor de Angústia, com o pai a respeito da expectativa do conteúdo do último capítulo da obra memorialística.

- Que é que pretende com o último capítulo?

Sensações da liberdade. A saída, uns restos de prisão a acompanhá-lo em ruas quase estranhas.

- Eu conhecia o Rio de 1915... ${ }^{32}$

Em seguida.

- Um fim literário.

Sim. No começo do livro e também nos outros volumes já fizera considerações numerosas, seria inútil concluir dessa maneira. Talvez surgissem pontos acidentais, desdobrasse a matéria em dois capítulos. Mas nada que pretendesse valorizar, tivesse influência no conjunto. Somente as primeiras sensações da liberdade. ${ }^{33}$

A explicação não destoa da imagem do escritor que uma leitura pessoal do texto de Graciliano Ramos formou durante a trajetória da pesquisa de sua obra. O homem doente e próximo da morte atravessou nas páginas de Memórias do cárcere o caminho que levou ao encontro consigo e com a realidade, num exercício de despersonalização absoluta, capaz de ser realizado apenas por aquele que planejava a obra final como póstuma. Entretanto,

${ }^{28}$ FAORO. Os donos do poder: formação do patronato político brasileiro, p. 819-838.

${ }^{29}$ Em Epos e romance (sobre a metodologia do estudo do romance) [1941], Bakhtin postula a especificidade estrutural do aspecto de gênero inacabado do romance. Agregando em seu processo de formação e evolução, elementos dos gêneros antigos, o romance "introduz uma problemática, um inacabamento semântico específico e o contato vivo com o inacabado, com a sua época que está se fazendo (o presente ainda não acabado"). (Cf. BAKHTIN. Questões de literatura e estética: a teoria do romance, p. 400.)

${ }^{30}$ RAMOS. Explicação final, p. 317.

${ }^{31}$ Refiro-me aos questionamentos surgidos na imprensa quanto à originalidade dos originais e das primeiras versões do livro. Ver a respeito o esclarecimento mais detalhado do próprio Ricardo Ramos em Graciliano Ramos: retrato fragmentado (1992).

${ }^{32}$ RAMOS. Explicação final, p. 319.

${ }^{33}$ RAMOS. Explicação final, p. 319. 
Memórias do cárcere, em vez de um fim literário, permite a abertura para a contemplação da obra do autor. Dessa maneira, a explicação colhida em Ricardo Ramos ganha pertinência quando enfocamos a atividade literária de Graciliano indissociável da própria vida. O que, de certa forma, a trajetória de seus textos e a leitura da crítica especializada corroboram. A publicação da obra póstuma provoca a abertura de um panorama que acolhe biografia, vida literária e período histórico como poucos eventos ocorridos na tradição literária brasileira. Ainda assim, guardo, pessoalmente, a opinião de que não há o último relato de Memórias do cárcere por que não seria honesto representar a liberdade em fevereiro de 1937, quando o autor deixa a prisão do governo ditatorial. ${ }^{34}$

Já o aspecto de texto inacabado de Angústia conjuga, indiscutivelmente, as circunstâncias factuais da finalização e publicação do livro e a aparência encenada do texto realizado na premência do ato de confissão.

Como toda interpretação é interminável, Luís da Silva está condenado a diferir, a dispersar-se em afirmações que não se mantém sob a exigência de uma (sic) zigue-zague objetiva e duradoura. A sua escrita, por isso, não tem valor de representação, não está no lugar de nada nem de ninguém, acentuando apenas o jogo abissal da diferença, a ruptura de um texto sempre divergente; por isso, sempre inconcluso, rebelde a qualquer perspectiva de revisão, o que o próprio autor custa a aceitar. ${ }^{35}$

Wander Melo Miranda aponta a especificidade e o efeito da opção pelo uso do “fragmento” em oposição à "linguagem do todo” na composição de Angústia. A escolha do procedimento opera a ruptura com o sistema social e o literário, e coloca o discurso do narrador numa posição de divergência, ou resistência. Estruturação do texto, lembra o crítico, condizente com a situação do intelectual pequeno-burguês de Luís da Silva, funcionário cooptado pelo Estado gerido pelo governo posto fora dos limites da legitimidade.

O efeito da conjunção do trabalho estético e da apreensão da mensagem textual veiculada pela forma do romance opera o agenciamento da plena consciência da linguagem

\footnotetext{
${ }^{34}$ A crítica do real proposta pela ficção possibilitará a exploração do tema. Silviano Santiago, no romance Em liberdade (1994), utiliza o ardil do diário fictício de Graciliano Ramos, posto em marcha logo após a saída da prisão, para justificar a impossibilidade da conclusão das Memórias do cárcere, iniciado dez ou onze anos após a prisão. Afinal, o relato "das primeiras sensações de liberdade” já havia sido elaborado. O que a realidade, junto à honestidade e a responsabilidade do autor de Angústia impossibilitaram, pode ser retomado pela imaginação e pelo poder crítico da ficção contemporânea. (Ver SANTIAGO. Em liberdade, p. 13-15.)
}

${ }^{35}$ MIRANDA. Graciliano Ramos, p. 36. 
e o recado a transmitir, apoiando-se no imperativo da responsabilidade do escritor, em que a fronteira entre estética e ética não se deixa apreender.

A reavaliação do critério de julgamento da composição de Angústia contou ainda com a opinião de Silviano Santiago: “Armado o contra-senso crítico, ali foi encerrado Angústia. Os 'defeitos’ de composição na frase e no discurso ficcional não empanam a ‘alta qualidade’ do romance (...) O romance é excepcional porque recebeu a composição justa." 36

Reconhecendo a originalidade do método composicional do romance, Silviano Santiago ratifica a natureza subversiva da narrativa de Luís da Silva. Fora do cânone lusobrasileiro, fora do cânone graciliânico, o romance de 1936 “decorre da 'psicologia de composição’ adequada, única e original dentro da literatura luso-brasileira. Ela vincula não só a temas universais, mas também aos 'defeitos’ assinalados pelos críticos em clássicos da literatura ocidental, como os romances de Honoré de Balzac ou Fiodor Dostoievski.” ${ }^{37}$

Mas é ao perscrutar o trabalho com a linguagem, realizado no romance, que o crítico nos possibilita apreender a relação entre os aparentes “defeitos” de composição e a mensagem do texto, compreendendo a dimensão do projeto estético do romance.

O modo verbal, de que se serve o narrador, condiciona a vinda da almejada revolução proletária à boa gramática e nos remete à boa sorte do futuro do pretérito (“quereriam fazer uma revolução...”). Se a negação da parataxe pela contaminação distancia Angústia dos outros romances de Graciliano, reconheçamos que esse importantíssimo detalhe verbal coloca todos no mesmo saco. Etiqueta: a freqüência no uso expressivo do futuro do pretérito. Celso Cunha e Lindley Cintra afirmam que se emprega esse tempo verbal "nas afirmações condicionadas, quando se referem a fatos que não se realizaram e que, provavelmente, não se realizarão". ${ }^{38}$

Em Angústia, há muita expectativa que não se realiza. Luís da Silva não se torna o descendente, com privilégios, de antigos senhores de terra. O relacionamento e o plano de casamento, a garantia da vida social estável entre Marina e o narrador não se concretiza. O assassinato de Julião Tavares não dá cabo da angústia sentida por Luís da Silva. O assassinato não concretiza nem mesmo o final da história, que se vê direcionada para o começo da narrativa num círculo temporal asfixiante; o cárcere pessoal do narrador. A expectativa da vida mediana representada por “um colchão de paina”, que dividiria com

\footnotetext{
${ }^{36}$ SANTIAGO. Posfácio, p. 292.

${ }^{37}$ SANTIAGO. Posfácio, p. 292-293.

${ }^{38}$ SANTIAGO. Posfácio, p. 297.
} 
Marina, não se realiza. Estas são as últimas palavras do romance. Elas encerram o discurso delirante do narrador. Como assinala Silviano Santiago, palavras não tão enigmáticas. ${ }^{39}$

A linguagem do narrador do romance impregna a linguagem do crítico. Apontamos o colchão de paina que dividiria com a mulher desejada e que se realiza apenas no delírio, a ascensão à classe média, que Luís da Silva pretenderia trilhar depois de resolvido o conflito social com o casamento que não aconteceu; enfim, o intelectual que gozaria da liberdade de expressão e viveria num país que lhe asseguraria a dignidade profissional que se vê numa condição diminuída no funcionalismo público aviltante. A retórica principesca do ditador não é eficiente a ponto de eliminar ou manter a repressão da memória das contradições que subsidiam a história de nossa formação por tanto tempo.

Para o narrador, resta a sorte e o bilhete de loteria proferido pelo cego no café: $16.384 !^{40}$ Graciliano Ramos ficou a cargo de atravessar e provocar a vigília causada pelo desvelamento das estruturas de um sistema inconcluso, encenando a narrativa pela voz de Luís da Silva após o período de alheamento causado pelo delírio, efeito das contradições levadas ao seu máximo. Acertando o foco da consciência após a convalescença do transtorno que lhe privara da lucidez, acompanhamos com Luís da Silva a tentativa de apreender a realidade através das sombras e da oscilação entre a memória e a imaginação; a insônia do narrador na travessia da angústia.

\begin{abstract}
RESUMEN
Análisis y crítica del proceso de escritura de la novela Angustia (1936), de Graciliano Ramos. El documento presenta una breve historia de protocolo de la composición de la obra y su recepción por la crítica. Entonces, la lectura del texto propuesto por la noción de la ilegitimidad, como demuestra la crítica del texto y la crítica del contexto histórico y cultural de su producción.
\end{abstract}

\footnotetext{
${ }^{39}$ SANTIAGO, Posfácio, p. 299.

${ }^{40}$ Em relação à alusão à falta de acabamento da estrutura sociopolítica brasileira, assim como à existência de uma situação política definida pelo regime republicano, existente apenas num nível de aparência, ver os trabalhos de Raymundo Faoro: Os donos do poder: formação do patronato político brasileiro (2001); A República inacabada (2007); e o de Renato Janine Ribeiro: A República (2001); “Democracia versus República: a questão do desejo nas lutas sociais” (2000).
} 


\section{Palabras Clave}

Graciliano Ramos, Angustia (1936), ilegitimidad

\section{REFERÊNCIAS}

BAKHTIN, Mikhail. Questões de literatura e estética: a teoria do romance. Trad. Aurora F. Bernadini. São Paulo: Hucitec, 1988.

BASTOS, Hermenegildo. Memórias do cárcere: literatura e testemunho. Brasília: Editora UnB, 1998.

BUENO, Luís. Uma história do romance de 30. São Paulo: Edusp; Campinas: Editora Unicamp, 2006.

CANDIDO, Antonio. Fiç̧ão e confissão. Rio de Janeiro: Ed. 34, 1992.

CARPEAUX, Otto Maria. Visão de Graciliano Ramos. In: RAMOS, Graciliano. Angústia. São Paulo: Círculo do livro, 1988. p. 192-201.

CARVALHO, Lúcia Helena. A ponta do novelo: uma interpretação de Angústia de Graciliano Ramos. São Paulo: Ática, 1983.

COUTINHO, Carlos Nelson. Graciliano Ramos. In: BRAYNER, Sônia. Graciliano Ramos. Coleção Fortuna Crítica 2. (Direção de Afrânio Coutinho). Rio de Janeiro: Civilização Brasileira, 1978. p. 73-122.

FAORO, Raymundo. A República inacabada. São Paulo: Globo, 2007.

FAORO, Raymundo. Os donos do poder: formação do patronato político brasileiro. São Paulo: Globo, 2001.

FREUD, Sigmund. Inibição, sintoma e ansiedade. In: Edição Standard das obras psicológicas completas de Sigmund Freud. Rio de Janeiro: Imago Editora, 1975. p. 107180. v. 20.

LINS, Álvaro. Valores e misérias das vidas secas. In: RAMOS, Graciliano. Vidas secas. Rio de Janeiro: Record, 1977. p. 136-167.

MALARD, Letícia. Ensaio de literatura brasileira: ideologia e realidade em Graciliano Ramos. Belo Horizonte, Itatiaia, 1976.

MIRANDA, Wander Melo. Corpos escritos: Graciliano Ramos e Silviano Santiago. São Paulo: Edusp; Belo Horizonte: Editora UFMG, 1992.

MIRANDA, Wander Melo. Graciliano Ramos. São Paulo: Publifolha, 2004.

MORAES, Denis de. O velho Graça: uma biografia de Graciliano Ramos. Rio de Janeiro: José Olympio, 1993.

MOURÃO, Rui. Estruturas: ensaio sobre o romance de Graciliano. Curitiba: Editora UFPR, 2003.

RAMOS, Graciliano. Caetés. Rio de Janeiro/São Paulo: Record, 2005.

RAMOS, Graciliano. Angústia. Rio de Janeiro/São Paulo: Record, 2005. 
RAMOS, Graciliano. Linhas tortas. Rio de Janeiro/São Paulo: Record, 1994.

RAMOS, Graciliano. Memórias do cárcere. Rio de Janeiro/São Paulo: Record, 2004. v. I, V. II.

RAMOS, Graciliano. S. Bernardo. 84. ed. Rio de Janeiro: Record, 2007.

RAMOS, Ricardo. Explicação final. In: RAMOS, Graciliano. Memórias do cárcere. Rio de Janeiro/São Paulo: Record, 2004. p. 317-319. v. II.

RAMOS, Ricardo. Graciliano: retrato fragmentado. São Paulo: Siciliano, 1992.

RIBEIRO, Renato Janine. A República. São Paulo: Publifolha, 2001.

RIBEIRO, Renato Janine. Da responsabilidade na Psicanálise. Disponível em < http://www.renatojanine.pro.br/Cultura/psicanalise.html >. Acesso em: 4 set. 2009.

RIBEIRO, Renato Janine. Democracia versus República: a questão do desejo nas lutas sociais. In: BIGNOTTO, Newton. Pensar a República. Belo Horizonte: Editora UFMG, 2000. p. 13-26.

SANTIAGO, Silviano. Em liberdade. Rio de Janeiro: Rocco, 1994.

SANTIAGO, Silviano. Posfácio. In: RAMOS, Graciliano. Angústia. Rio de Janeiro/São Paulo: Record, 2005. p. 287-300. 